\title{
THE ROLE OF DIGITAL MARKETING IN PROMOTION OF WINE FROMAP KOSOVO AND METOHIJA
}

\author{
Nebojsa Denic ${ }^{1}$, Borislav Radevic ${ }^{2}$, Boris Siljkovic ${ }^{3}$ \\ *Corresponding author E-mail: nebojsa.denic@pr.ac.rs
}

A R T I C L E I N F O
Review Article
Received: 10 April 2018
Accepted: 17 August 2018
doi:10.5937/ekoPolj1803071D
UDC 663.2:004.738.5(497.115)

Keywords:

digital marketing, wine promotion, brand, customer value, Kosovo and Metohija's wine

JEL: F20, F21, O52, O57, P20, P52.

\section{A B S T R A C T}

The territories of AP Kosovo and Metohija represent the challenging and fast-growing wine market. However, many wine producers from Kosovo and Metohija are forced to acquire an innovative marketing approach which provides enhanced consumer experience and value. Therefore, they have implemented various marketing strategies in order to develop a positive brand reputation and create new opportunities for small and medium-sized wine producers. This paper aims to inspect the role of digital marketing in promotion of wine from Kosovo and Metohija, which enables producers to combine and integrate different marketing techniques in order to promote their strengths, that is, brand. Based on the primary data collected through the questionnaires, in-depth interviews and surveys, this study attempts to show how using digital marketing is statistically significant with reported increases in wine sale. The findings show that digital marketing facilitates the implementation of various marketing strategies which can improve the value of the consumption experience offered to the customer.

(C) 2018 EA. All rights reserved.

\section{Introduction}

Research studies have shown that in the last two decades wine production has become increasingly competitive and globalised, while the wine marketing is considered to be information-intensive (Stricker et al., 2007). During the years, trade barriers have diminished, communication have become almost instantaneous, and consumer behaviour has evolved from traditional to experimental. Producers concerned with marketing have had to adjust production, distribution, and marketing strategies to cope with these changes. Due to the rapid development of e-commerce technologies (Quinton and Harridge-March, 2003) which is coupled with the global consumption

1 Nebojsa Denic, PhD, Associate Professor, University of Pristina, Faculty of Sciences and Mathematics, Kosovska Mitrovica,Serbia, e-mail: nebojsa.denic@pr.ac.rs

2 Borislav Radevic, PhD, University of Priština, Faculty of Economics, Kosovska Mitrovica, Serbia

3 Boris Siljkovic, PhD, Assistant Professor, Faculty of Trade and Banking, Alfa University, Palmira Toljatija 3, 11070 Belgrade, Serbia, Phone: + 381656265 211, e-mail: boris_siljkovic@gmail.com 
of wines (Bernetti et al., 2006), there are many opportunities for the wineries which decide to use direct marketing channels, such as the Internet (Bruwer and Wood, 2005). Its tools and applications have allowed small and medium-sized wineries to become highly competative at global market.

The art of wine-making in the area of AP Kosovo and Metohija is more than 2,000 years long. There are a numerous archaeological findings, historic data and various toponym $\mathrm{s}$ that indicate that the wine production dates back to the Serbian royal house of Nemanjić who promoted wine growing and outlawed the practice of adding water to wine. Later, Emperor Dušan the Great made a $25 \mathrm{~km}$ long "wine pipeline" which transported wine from his vineyards to his court in Prizren. According to the vinopedia.rs, in 1988 there was 9,000 hectres of vineyards in the territory of Kosovo and Metohija, while today the area covered by vineyard totals 3,220 hectares. There are two main wine growing regions within AP Kosovo and Metohija which should be mentioned. The first is known as North Methohija region which spreads on the terrains in the northwest part of Metohija from the slopes of Mokra Gora in the north to the river Pećka Bistrica in the south, and it has two wine growing districts: Istočko and Peć. South Metohija region is the second main region which spreads in the southwest part of Kosovo and Metohija, that is, in the area of South Metohija. It has five wine growing districts: Đakovica, Orahovac, Prizren, Suva Reka and Mališevac (Ivanišević, Jakšić, 2014). When it comes to exporting Kosovo and Metohija's wine, number one destination for wine sale is Serbia (13,289,071 litres), followed by exports to Germany (6,194,042 litres), Croatia (9, 090,383 litres), Macedonia (2, 809, 194 litres) and Slovenia (2,881,026 litres).

In the world where companies attempt to adapt to consumer empowerment in order to achieve a greater profitability, understanding consumer's needs is possible through an adequate marketing approach which will provide increased sales of domestic wine and the quicker development of the national market (Radovanović, Đorđević \& Petrović, 2017). Digital marketing has been proven tool which helps producers to achieve their goals. However, in AP Kosovo and Metohijadigital marketing does not have a significant presence, despite the fact that there are many internet users.

In Kosovo and Metohija, producers appear to be on the fence when it comes to using the benefits of digital marketing; they have still not figured out whether the opportunities outweigh the challenges. While acknowledging that the topic needs more extensive research, this paper analysis the main advantages and challenges associated with the implementation of an online marketing strategy and ways of brand activation of wine in the territories of AP Kosovo and Metohija. The basic hypothesis in this paper is that the digital marketing influences the decision on the purchase of wine. Therefore it is necessary to analyse the influence of factors on making a decision to purchase and consume wine, in order to understand the behaviour of consumers. After a brief discussion on the characteristics of the wine marketing in general and the presentation of wine production in Kosovo and Metohija, the paper explores factors that influence the purchase of wine, as well as opportunities for implementation of digital marketing in Kosovo and Metohija. The research methodology applied to collect and analyse data 
is then presented, and the findings are discussed in direct relation to the formulated research objectives. This research concludes with a summary of the main result and with propositions for future investigation on this subject.

\section{Material and methods}

In this research work, on the basis of combined methods of studious analysis and comparisons of theoretical postulates with research in the area of Kosovo and Metohija, it was attempted to find adequate solutions to the problem of placing wines from these areas.

Mainly due to globalization, there is an increase in competition on the wine market. There are 3 driving forces that lead to stronger competition and represent the greatest influencers of the increasing competition in the wine market (Abegão, 2016):

1. worldwide over-supply of grapes and incumbent pricing pressures, due to favourable weather conditions and consequent increase in plantings, and "low price/high quality" product strategies being applied by many wine companies;

2. increased consolidation at producer, distributor and retailing sectors, since as winery grow their business, their tendency is to merge with other companies to obtain a stronger position in the market;

3. shifting consumer behaviour patterns, which may affect the business of wineries if they do not adjust their strategy.

Kotler and Keller (2006) examined the wine market in order to identify the attributes of wine that have the most significant influence on the decision of consumers when purchasing certain wine. A strategic advantage is the existence of a product that has a protected designation of origin as a quality factor of this product (Bruwer\& House, 2003).

\section{Wine production in Metohija andchallenges in operating a winery}

At its peak in 1989, Kosovo boasted 9,000 hectares of vineyards, divided into private and public ownership, and a major export business (40 million liters that year to Germany alone) (Nurre Jennions, 2017).

Wine industry in Kosovo and Metohija collapsed in 1990s, when the former Yugoslavia fell apart, and much of its infrastructure was destroyed by war. After the fighting subsided, a number of state-owned wineries were privatised, and production began to recover. There are signs that a once-thriving industry is getting back on its feet (Tabak, Hugh-Jones, 2011), especially after a symposium held in Orahovac/Rahovec in 1997 that initiated an annual festival to celebrate the grape harvest and the region's wine producers.

Today, Kosovo has some 3,000 hectares of vineyards and 15 wineries that range in size from formerly state-owned behemoths to small family wineries. Two big enterprise 
operational in Orahovac/Rahovec (Stone Castle) and Suva Reka(Agrokosova Holding) have been privatized, and currently cover an area of 850 hectares of vineyards, comprising $27 \%$ of the total area of active vineyards in Kosovo.

The area of Orahovac/Rahovec vineyards has ideal conditions for producing high-quality wines, using different varieties of grapes. It is a part of southern sub-region of Kosovo and the most prominent area of Kosovo vineyards and winery. All vineyards lie along the hilly terrain and the moderate continental climate make this area very specific imbuing it with special properties for production of high quality and premium grapes and wines. Grape varieties mainly (around 65\%) belong to red grape. The most representative cultivars are: Cabernet Sauvignon, Merlot, Pinot Noir, Vranac, Prokupac and Tamjanika. "Stone Castle" winery is the largest region's winery, with a capacity to produce up to 30 million liters per year. It, also, contributed to the local economy by purchasing from area's farmers. Just outside of Orahovac is the scenic Serbian village of Velika Hoča, known for having 13 churches for its 120 residents, and as the place where the monks of Dečani Monastery have been producing wine since the $15^{\text {th }}$ century.

Some of the most famous wineries on the ninth of the marked wine routes in Serbia are Vinica Petrović from Velika Hoča, as well as Antić winery from Orahovac. They make wine using Italian Riesling, the Rhein Riesling, Red Burgundy, Vranac, Sauvignon and Cabernet sorts (Serbia.com).

Figure 1:Panorama of the Orahovac vineyards.

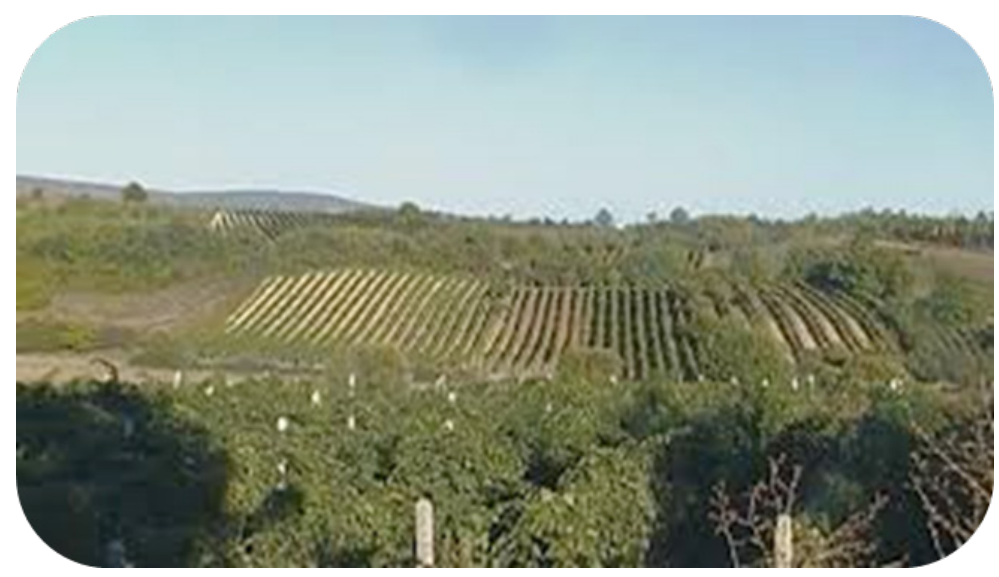

Source: http://www.vinopedia.rs

\section{Factors that influence consumer purchase decisions}

Many factors influence consumer behaviour toward wine. Perhaps the greatest shift in consumer purchase behavior over the past decades has been from table wines to quality wines, particularly in traditional wine-drinking countries (Lapsley \& Moulton, 2001).There are many factors such as the bottle shape, colour, the type of closure (cork, technical composite or screw top), the grape, the winemaker's skills and label 
presentation (design, information provided, logo) that influence consumer choice in purchasing wine (Jennins and Wood, 1994; Barber, Almanza, Donovan 2006). However, each decision-making process starts with the recognition of need.

Marketing is an important technique for wine promotion, as well as branding. However, while marketing activates buyers convincing them to purchase a particular brand (wine) - branding makes loyal customers. Building customer loyalty is the ultimate goal for wine producers and the perceived quality of wine raises the quality expectation (Hussain, Cholette, \&Castaldi, 2007).

According to House (2003), regionality helps to differentiate a product and create a clear association between product brand and region of origin. Within AP Kosovo and Metohija, Orahovac Valley has secured the top position and is most recognized as a quality wine region, therefore, its wine represents the regional brand. Bruwer and House (2003) claimed that region-of-origin ranked third behind price and grape variety in consumers' wine-buying decision.

Figure 2illustrates that 85 per cent of wine consumers indicated that they consider the region when assessing a wine label. This was the most important factor, more important than brand name, label image, appellation, vintage, alcohol content, country or state.

Figure 2.Information on wine labels used to gauge quality

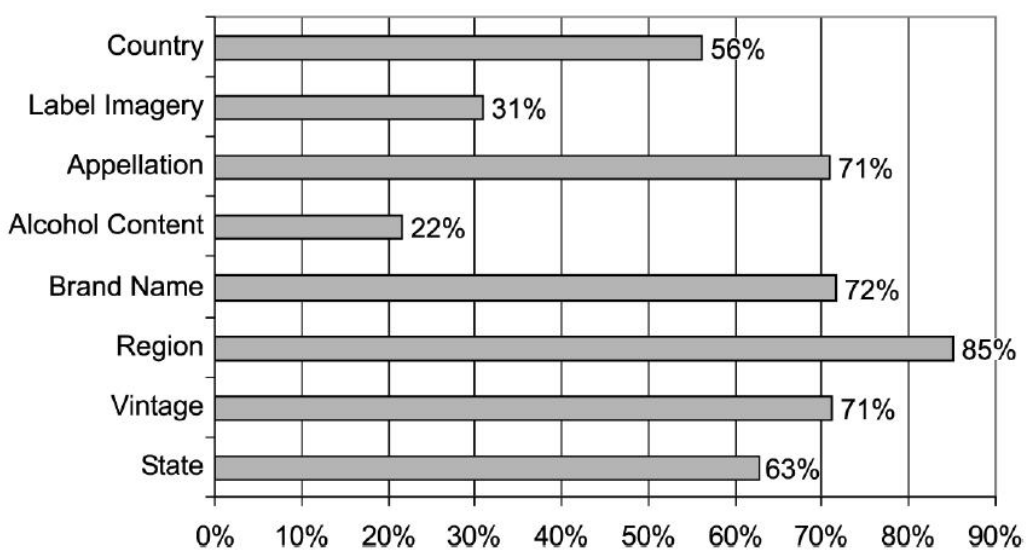

Source: Regional brand image and perceived wine quality: the consumer perspective (2018)

The acknowledged wine critic Jerry D. Mead said that "60 percent of wine sales are based on that ever-elusive air around the bottle". In fact, Mead was referring to the importance wine packaging has over the consumer's purchasing decision (Sawyer, 2006). However, wine has a unique constraint that sets it apart from other products, because the quality of the wine itself cannot be assessed until it has been consumed (Lockshin, 2001; Fernandes Ferreira Madureira\&Simoes de Sousa Nunes, 2013).

Wine consumer goes through five stages before the actual purchase. Consumer recognizes the need, gathers information, evaluates alternatives and makes the purchase decision. When the purchase is done, the consumer evaluates the received satisfaction level (Kotler \& Armstrong, 2010). 
In order to create an effective marketing, it is important to understand target audience's behaviour during the whole decision-making process (Kotler \& Keller, 2012), which can be summarized through the following stages:

1. Need recognition \& problem awareness. The need recognition is the first stage of the consumer decision process in which consumer recognizes what the problem or need is and what kind of product would be able to meet this need.

2. Information search. At the second stage, the consumer gathers information from multiple sources -by talking with friends, reading magazines or using the Internet, or by using internal search which refers to the information a consumer has stored in their memory about a particular product.

3. Evaluation of alternatives. The next stage is the evaluation of alternatives which involves the evaluation of alternative brands in the product category. The consumer evaluates alternatives and makes a choice based on the various criteria (i.e. time and money costs, how much information the consumer already has, the amount of the perceived risk if a wrong selection is made, etc.)

4. Purchase. At this stage, the consumer is ready to buy certain product.

5. Post-purchase behaviour. The consumer will compare products with their previous expectations and will distribute their positive or negative feedback about the product, which can be done through reviews on website, social media networks or word-of-mouth.

The emergence of the Internet helped wine companies to advertise their products, to target the right audience, and to measure responses instantly. Advertising became a marketing communication tool that refers to the differences and similarities between customer's perception and company's expectations. Due to the development of digital marketing, companies are able to set up official brand pages on Internet, particularly on social media sites, and post updates to consumers however often they choose. Internet and digital marketing can help companies grow their business and increase brand awareness. However, most companies have not yet adopted the new technology.

For buyers looking for places to go tasting wine, Internet is a perfect chance to make a great first impression with a captivating image of winery tasting room, vineyards, cellar, etc. Unfortunately, some wineries with some picturesque tasting rooms completely fail to convey this beauty on their websites. According to vinboundmarketing.com, the bulk of consumers will spend at least an hour online visiting websites after website to plan out their ideal tasting trip.

Therefore, digital marketing is said to have and impact on consumers' behaviour and personal attitudes towards the particular wine brand. It can be stimuli for buyers to pay attention to the product, compare it with what other companies in the same marketing niche are saying, and finally make a decision concerning the product (Rodgers \& Thorson, 2000). 


\section{Web Advertising}

Web advertising can be presented in several forms such as hyperlinks, interstitials, and pop-ups (Rodgers and Thorson, 2000) and it generally refers to the small, hyperlinked pixel banners popping up on Web sites (Rex B. and Hollis N., 1997). According to Ducoffe (1996), Web ads are more relevant to consumers compared with traditional ads, which also implies that online users tend to perceive the ads to be self-related or instrumental in achieving their needs and values (Maclnnis and Jaworshi, 1998). It is able to take advantage of addressable media technology to select appropriate ads that fit with users' online behaviours, and thus make the ads more relevant to consumers.

According to some previous research, the users consider sponsored links to be more informative, more entertaining and less striking than web banners. However, users find web banners more visible than sponsored links. In practice, producers from Kosovo and Metohija are not adequately familiar with the opportunities of digital marketing, despite the fact that there are reasons for success of it in Kosovo and Metohija. The main reasons why it can succeed are: low cost compared to traditional marketing (TV, radio, billboard, etc), a positive attitude of businesses towards digitalization, a large number of potential customers, and increased need for professionals in this field. Compared to traditional media, which is expensive and can reach limited audiences, digital marketing tools provide opportunities to advertise to anyone in the world with access to these digital tools. In Table 1 is presented a comparison of traditional marketing with digital marketing.

Table 1:Traditional Marketing vs. Digital Marketing

\begin{tabular}{|l|l|l|}
\hline & Traditional Marketing & Digital Marketing \\
\hline Reach & limited & global \\
\hline Accessibility & limited & diverse \\
\hline Communication & one-way & two-way \\
\hline Availability & limited & very quick \\
\hline Targeting & hard & easy \\
\hline Measurement & hard & easy \\
\hline
\end{tabular}

Source: Author's own empirical work

According to the KPM (Independent Media Commision), 90\% of businesses in Kosovo agree that digitalization not only cuts advertising costs, but it also improves the advertising quality. Chaffey (2015) points out that Internet usage keeps growing every day and it is used by more than $40 \%$ of the world's population.

The study conducted by KPM shows that $67 \%$ of businesses in Kosovo think that advertising plays a key role towards a company's success. A study by STIKK (2013) shows that in Kosovo, internet penetration is at about $77 \%$, which is a high percentage. 


\section{Wine Banding}

Branding is a very important factor that makes or breaks the winery's sales. It is about individuality of each consumer and how he perceives brand values (Brandon, 2017) According to American Marketing Association Dictionary (1960), a brand is "A name, term, design, symbol, or any other feature that identifies one seller's good or service as distinct from those of other sellers." In other words, brands are a means to differentiate from the competitors (or future competitors).

Christian Seely (2010) points out that a brand could aid value, where value is the highest price possible, at which a consumer will be enthusiastic to pay for a bottle of wine. Wine branding is also an efficient way for growth, giving a competitive advantage, but with a heavy local market dependency. "Brand performance is strongly influenced by geographical and market contexts and above all by culture. Technical criteria tend to be of less importance". According to Moulton \& Lapsley (2006), wineries are divided into production-oriented and marketing- oriented, which is presented in Table 2.

Table 2:Types of wineries

\begin{tabular}{|l|l|}
\hline Production-oriented wineries & Marketing-oriented wineries \\
\hline High production costs & Low production costs \\
\hline Low product cost & Price-sensitive products \\
\hline High product quality & Value orientation \\
\hline Product source is important & Product origin is not of great importance \\
\hline Production quantity is limited by quality & Production quantity is limited by demand \\
\hline Quality/trademark relation & Price/Trademark Relation \\
\hline Low-cost ways of sales and marketing & High-cost of sales and marketing \\
\hline
\end{tabular}

Source: K. Moulton \& J. Lapsley, Successful Wine Marketing 2006, p. 100.

The eminent author, Spawton (1990) contends that the major influences on wine purchase decision are: perceived risk; product cues such as brand, label and price; product experience and knowledge; and the product-use situation. This implies that an understanding of what quality means to consumers offers the promise of improving brand positions through more precise market segmentation, product planning, promotion, and pricing strategy (Zeithaml, 1998).

Due to the fact that the wine industry has entered a stage where just making good prodicts is not enough to grow the market, producers offered a wide choice of wines available for consumers and wineries need to move from a production orientation to a marketing orientation based upon understanding the consumer (Thomas, 2000). Consumer perceptions of price, quality, and value are considered to be pivotal determinants of product choice. 


\section{Results and discussion}

Research indicates that majority of wine from Kosovo and Metohija is sold through supermarkets and other large retailers. However, this is not an ideal marketing channel for smaller wineries, as they cannot supply the required volumes and compete with larger brands. Larger wineries are more focused on the production of prestigious and quality wines (Nella \& Christou, 2014). Geographic branding has become an important strategy for economic actors to differentiate their products (Patel-Campillo\&DeLessioParson, 2016).

In the conditions of the current economic crisis and dynamic and highly competitive economy, the majority of research on the direct marketing of wine has focused on the digital marketing. Due to the rapid development of e-commerce, the engagement in direct sales with customers is much easier. Husain et al., (2008) suggested that small wineries should exploit technology to establish direct contact with wine consumers and they can benefit through using internet technologies to sell wine.

For a successful marketing of wine, individual wine must be unique in taste, to clearly indicate the region from which it originates in order to become easily recognizable to consumers. However, the major concerns of the wine producers from Kosovo and Metohia are no longer related to the improvement of the technical-qualitative aspect of their product, but rather to knowing in advance the nature of an expanding and increasingly volatile demand and what the direct competitors are able to offer. In addition to the issue of wine marketing and with insufficient and incomplete knowledge of concepts of internet marketing, advertising and branding, the producers particularly highlighted the following problems in operating of wineries in Metohija region:

$\checkmark$ Double taxation, double excise,

$\checkmark$ Kosovo's purchasers carry out extortion in price, and money is paid out in May next year. This could be prevented by Serbian government, so that money can be given to producers immediately after the purchase. For this reason, the Albanians prefer to sell grapes to the Serbian producer.

$\checkmark$ Provisional Institutions in Kosovo and Metohija encourage wineries with $€ 1000$ per hectare of vineyard a year, while according to the Serbian producers, the relevant ministry and authorities of the Republic of Serbia have so far granted loans with stimulating interest and donations in presses, crushers, vats, etc.

$\checkmark \quad$ For now, there are no incentives for wine production in Serbian environments and exports, which should be done, especially in the circumstances in which people from Kosovo and Metohija live.

$\checkmark \quad$ In 2015, the purchase price of grapes was 26-30 cents for "Vranac" which is predominantly purchased because it is good for mixing, blending, etc.

$\checkmark \quad$ The selling price of white and red wine in plastic bottles is 150-190 dinars per litre, 
$\checkmark \quad$ The selling price of white and red wine in a glass bottle of 0.75 litres is $4-4.5$ euros ( 38 cents per bottle, 50 cents per cork, 10-12 cents per labels and transportation, the price depends on the destination).

$\checkmark \quad$ Export of plastic and glass bottles is mostly done, in small quantities from 20 to 40 bottles in vans and buses, but not in tanks due to problems with the Kosovo police, sanitary inspection, etc.

$\checkmark$ "Navip" from Serbia gave a bid to buy the entire wine production for 55 cents per litre, but the owner of the Antic winery rejected the bid because it was not profitable.

\section{Conclusion}

The utilization of digital marketing (electronic platforms and digital devices) can facilitate the promotion of a particular wine brand. This study tried to show how Kosovo has done great job following global trends of digitalization, but it still lacks in utilizing this market for marketing reasons, staying closer to the customer and satisfying their needs. Opportunities for wine promotion using digital marketing would benefit customers, since today, a crucial success factor for business is to follow consumer trends and satisfy customer needs while being there wherever the customer is. The current economic crisis and the complex situation in Kosovo and Metohija region force wine producers to differentiate their products using different marketing strategies, such as production-oriented and marketing-oriented. Many wine producers use the brand strategy as one of the possible marketing strategies. In particular, building zour own brand is important for those wineries who want a breakthrough on a foreign market. The findings indicate that winery owners from Kosovo and Metohija region have severe problems with the benefits of digital marketing due to a specific living and business conditions. They are not adequately familiar with the advantages of Internet marketing and are unable to use these comparative advantages because of poor internet connection. The results of a studious research given in this paper indicate that one of the solutions to the problem is the introduction of the concept of Internet marketing, advertising and branding that requires additional effort from small and medium-sized enterprises, both in terms of investments and in terms of the competencies they have to build in order to comply with complexities which this topic brings. It is, also, evident that producers are faced with increased competition, since global wine production is in expansion, and it is expected that the introduction of alcohol abuse prevention law shall come into force. This will significantly contribute to the winery's business performance, as well as it will lead to future customer satisfaction.

The results of the research presented in this paper confirmed the hypothesis that the brand, image and label are very important factors in purchasing wine. The findings show that a design of a particular brand is an extremely important factor for the success of winemakers. When purchasing a particular wine brand, previous experience, friends' recommendations and internet reviews, as well as geographical origin and image of brand are of great importance. 
Presented research results in the analysis of users' attitudes towards internet advertising round the world generally differ. Some relevant studies have shown that users have a positive attitude towards internet advertising. The majority of research papers emphasize 3 factors that have major influence on creation of attitude towards internet advertising or online ads: the quality of being informative, entertaining and striking. The qualities of being interactive and credible were also mentioned. Some well-known authors point out that users have different attitudes towards different forms of online ads, i.e., users finds some form of online ads more appealing than others.

Although it is difficult for owners of small and medium-sized wineries in Kosovo and Metohija region to use advanced technologies and advertising tools due to lack of financial resources, it is still necessary to include methods and strategies of digital marketing in order to solve the problems with wine promotion and sale.

\section{Conflict of interests}

The authors declare no conflict of interest.

\section{References}

1. Abegão M. L. C. (2015). Impact of wine labels change on consumer preferences - The case of Fiuza \& Bright. Retrieved from https://run.unl.pt/bitstream/ 10362/18249/1/Abeg\%C3\%A3o_2016.pdf(July 10, 2018).

2. Ahmeti B. (2015). Digital Marketing Insights and Opportunities in Kosovo. Retrieved from https:/www.researchgate.net/publication/307820767_Digital_ Marketing_Insights_and_Opportunities_in_Kosovo (July 7, 2018).

3. AtkinT.\&Sutanonpaiboon.(2007).AMultinationalStudyofGenderWinePreferences. Retrived from https://www.researchgate.net/publication/228755508_A_ Multinational_Study_of_Gender_Wine_Preferences (July 18, 2018).

4. Barber N., Almanza B. A., Donovan J. R., (2006) Motivational factors of gender, income and age on selecting a bottle of wine, International Journal of Wine Marketing, Vol. 18 Issue: 3, pp.218-232.

5. Bernetti I, Franciosi C., Lombardi G.V. (2006). Land use change and the multifunctional role of agriculture: a spatial prediction model in an Italian rural area. International Journal of Agricultural Resources, Governance and Ecology, 5 (2-3), 145-161.

6. Bruwer, J. \& House, M. (2003). Has the era of regional branding arrived for the Australian wine industry? Some perspectives, The Australian \& New Zeland Grapegrower \& winemaner, 479: 56-61.

7. Bruwer, J. and Wood, G. (2005). The Australian Online Wine-buying Consumer: Motivational and Behavioural Perspectives. Journal of Wine Research, 16 (3), 193-211. 
8. Chaffey, Dave. (2015). Digital Marketing Statistics. Smart Insights. Smart Insights, 6 Janar 2015

9. Choices Magazine, 22 (1). Retrieved from http://www.choicesmagazine. org/2007_1/foodchains/2007_1_06.htm (June 28, 2018).

10. Ethno villages. Wine Routes. Retrieved from http:/www.serbia.com/visit-serbia/ enjoy-serbia/ethno-villages/ (July 10, 2018).

11. Ivanišević D. i Jakšić D. (2014). Viticulture in Serbia According to Statistics and Viticulture Zoning [in Serbian: Иванишевић Д. и Јакшић Д. (2014). Виноградарство у Србији према статистичким подацима и виноградарској зони].

12. Jennings D., Wood C., (1994). Wine: Achieving Competitive Advantage Through Design, International Journal of Wine Marketing, Vol. 6 Issue: 1, pp.49-61.

13. Jennions B. N. (2017). 5 Wineries Putting Kosovo on the Map. Paste Magazine, July 28, 2017. Retrieved from https://www.pastemagazine.com/articles /2016/09/5wineries-putting-kosovo-on-the-map.html (July 15, 2018).

14. Kosovo Wine Absurdistan. Retrieved from http:/www.vinopedia. $\mathrm{rs} / ? \mathrm{p}=7029 \&$ lang=en (July 1, 2018)

15. Kotler P. \& Armstrong G. M. (2010). Principles of Marketing. Prentice Hall, Pennsylvania State University.

16. Kotler P. \& Keller K. L. (2012). Marketing Management, 14th Ed. Pp. 191-199. Pearson, London.

17. KPM. Analiza e Tregut të Reklamës në Kosovë. Komisioni i Pavarur për Media. Komisioni i Pavarur për Media, Shtator 2013.

18. Lapsley J. \& Moulton K. (2001). Successful Wine Marketing. Springer, New York.

19. Lockshin, L., Rasmussen, M. and Cleary, F. (2000), The nature and roles of a wine brand, Australia and New Zealand Wine Industry Journal Special Issue on Wine Marketing, Vol. 15No. 4, pp. 17-24.

20. Mahmood Hussain, Susan Cholette, Richard Castaldi, (2007). Determinants of wine consumption of US consumers: an econometric analysis, International Journal of Wine Business Research, Vol. 19 Issue: 1, pp.49-62.

21. Nella A. \& Christou E. (2014). Segmenting Wine Tourists on the Basis of Involvement with Wine. Retrieved from https://www.researchgate.net/publication/280172371 Segmenting_Wine_Tourists_on_the_Basis_of_Involvement_with_Wine (July 6, 2018).

22. Patel-Campillo A. \& DeLessio-Parson A. (2016) Why types of operations, trade associations, and production trends matter in the geographic branding of an emerging industry. Journal of Wine Research, 27 (3). pp. 242-256.

23. Pierre M. (2009). Is Branding An Efficient Tool For Wine Industry?; International Journal of Case Method Research \& Application [The World Association for Case Method Research \& Application 2009]. Retrieved from http:/www.wacra.org/ PublicDomain/IJCRA\%20xxi_ii_pg128-139\%20Mora.pdf (July 5, 2018). 
24. Quinton, S. and Harridge-March, S. (2003). Strategic interactive marketing of wine - a case of evolution. Marketing Intelligence and Planning, 21 (6), 357-362.

25. Radovanović V., Đorđević D. Ž. \& Petrović J. (2017). Wine Marketing: Impact of Demographic Factors of Serbian Consumers on the Choice of Wine. Economic Themes (2017) 55 (2): 199-215. DOI 10.1515/ethemes-2017-0012. Retrieved from https:/www.degruyter.com/downloadpdf/j/ethemes.2017.55.issue-2/ ethemes-2017-0012/ ethemes-2017-0012.pdf. (July 7, 2018).

26. Regional brand image and perceived wine quality: the consumer perspective. International Journal of Wine Business Research, 19(4), p.289. Retrieved from https:/www.researchgate.net/publication/235278261_Regional_brand_image_ and_perceived_wine_quality_The_consumer_perspective (July 1 2018).

27. Relevant attributes of Portuguese wines. Retrieved from: https://www.researchgate. net/publication/279413677_Relevant_attributes_of_Portuguese_wines Matching_regions_and_consumer's_involvement_level_(July 20, 2018).

28. Rex B. and Hollis N. (1997). Advertising on the Web: Is There Response before Click-Through? Journal of Advertising Research, 37 (April), 33-45.

29. Shelly R. and Thorson E. (2000). The Interactive Advertising Model: How Users Perceive and Process Online Ads. Journal of Interactive Advertising, 1(1). Retrieved from http://jiad.org/voll/no1/rodgers/index.htm (June 25, 2018).

30. STIKK. (2013). Internet Penetration and Usage in Kosovo. STIKK. STIKK Kosovo Association of Information and Communication Technology, Gusht 2013.

31. Stricker, S., Mueller, R. A. E. and Sumner, D. A. (2007). Marketing Wine on the Web,

32. Tabak N. \& Jones R. H. (2011). Kosovo's wines flowing again. Retrieved from https://www.bbc.com/news/world-europe-15401459 (July 15, 2018).

33. Three Big Mistakes your winery is Making Online. Retrieved from https://www. vinboundmarketing.com/three-big-mistakes-your-winery-is-making-online/ (July 15, 2018).

34. Who serves the wine consumer best. (2018). Retrieved from https:// www.mastersofwine.org/en/events/symposium-2018/previous-symposia/ bordeaux-2010/forging-links-videos/who-serves-the-wine-consumer-best.cfm (July 11, 2018).

35. Wine Branding. A Useful Tool for Sales, or Not? Wineoctopus. July 7, 2016. Retrieved from https://wineoctopus.com/2016/07/07/wine-branding-a-useful-toolfor-sales-or-not/ (July 7, 2018).

36. Zeithaml, V.A. (1998) Consumer Perceptions of Price, Quality, and Value: A MeansEnd Model and Synthesis of Evidence. Journal of Marketing, 52, 2-22. 